\title{
Suckling behaviour of West African dwarf goat kids
}

Iyasere, O. S., James, I. J., Akinsanya, O. O, Williams, T. J. and Daramola, J. O. Department of Animal Physiology, Federal University of Agriculture, Abeokuta, Nigeria.

Abstract Corresponding author: o.s.iyasere@gmail.com; +234-8169004136

During suckling, goat kids exhibit different kinds of behavior which could be germane to their general performance. The objective of this study was to determine suckling behaviour of West African dwarf (WAD) goat kids with respect to some behavioural measurements. A total number of 21 WAD does comprising of $1^{\text {st }}$ and $2^{\text {nd }}$ parity with live weight range of $9.5 \mathrm{~kg}-16.5 \mathrm{~kg}$ with a total of 26 kids (12males and 14females) in a small holder dairy goat were used. Data on suckling behaviour (suckling bout, duration of suckling and number of butts during suckling) was monitored to investigate the effect of birth type (singleton and twin) and kid sex (male and female). Behaviours were observed twice/day i.e. in the morning (7:00-8.30 am) and evening (4:30-6:00pm), 2 days/week starting from the $2^{\text {nd }}$ week after kidding for 7 weeks. Suckling bout, duration of suckling and number of butts during suckling was greater in twin than in singleton. Kid sex had no significant effect on all behavioural parameters monitored. However, significant positive correlations were observed between suckling bout and number of butts during suckling, between suckling bouts and duration of suckling and between duration of suckling and number of butts during suckling. In conclusion, suckling behaviours in WAD kids were dependent on the birth type and not sex of the kids.

\section{Keywords: parity, sex, suckling behavior, West African dwarf goats}

\section{Introduction}

Goat production requires low capital investment and higher return on investment within two years (Baruwa, 2013) probably because of their short gestation period and their prolific nature in giving birth to twins and triplets compared to cows. In Southwestern Nigeria, $91.7 \%$ of goat farmers keep WAD goats while 5\% and 3.3\% keep the Red Sokoto and Sahel respectively (Baruwa, 2013) which contributes significantly to the livelihoods of impoverished families. Goats are reared both by christians and muslims which implies that there was no religious barrier to the rearing of goats in Nigeria (Ogunniyi et al., 2014). Good mothering ability is essential for the survival of the neonate, because the dam is the sole source of food for the pre-weaned kids, hence the need for the neonate to gain access to the teat as soon as possible after birth (Awotwi et al., 1999).
Early suckling is important for the establishment of a bond with the mother (Keverne, 1988). Moreso, the inability of kids to suckle has been identified as one of the factors causing pre-weaning mortality in South African Angora goats (Snyman, 2010). During suckling, the kids exhibit different kinds of behavior which could be referred to as 'suckling behaviour'. Reduced suckling frequencies and/or growth rates in twins relative to singletons have been reported in domestic sheep (Ewbank, 1967) and cattle (Price et al.,1985), indicating the existence of sibling competition for the teat during suckling. Several researches have focused on the milk yield (James and Osinowo, 2004; Williams et al., 2012; Williams et al., 2015) in WAD goats. Recently, short term separation of WAD dams from kids prior to milking of the dams was reported to be stressful to the dams (Iyasere et al., 2015). However, there is no 


\section{Suckling behaviour of West African dwarf goat kids}

investigation on the suckling behaviour of the WAD goat kids. Therefore this study was designed to investigate the suckling behaviour of West African Dwarf goat kids.

\section{Materials and methods Experimental site}

The study was conducted in a small holder dairy goat farm in Abeokuta, Ogun state. This region is a tropical humid climate with an elevation of $141 \mathrm{~m}$ and altitude of $286.5 \mathrm{~m}$ above sea level, located in the forest zone of South Western Nigeria which lies along latitude $3^{0} 25^{\prime} 55.67^{\prime \prime} \mathrm{E}$ and longitude $7^{0} 11^{\prime}, 30.65^{\prime \prime} \mathrm{N}$, with an average rainfall of $1037 \mathrm{~mm}$ and temperature of about $34.7^{\circ} \mathrm{C}$.

\section{Experimental goats and management}

A total number of 21 West African dwarf dams consisting of $1^{\text {st }}$ and $2^{\text {nd }}$ parity with the live weight range of $9.5 \mathrm{~kg}-16.5 \mathrm{~kg}$ with a total number of 26 kids (12males and 14 females) were kept under an intensive system in a well-ventilated open sided pen (dimension of $1.65 \mathrm{~m} \times 1.30 \mathrm{~m}$ per pen) with slatted concrete floor. Dams were fed with concentrate in the morning and Panicum maximum in the evening and water was provided ad libitum.

\section{Behavioural observation}

Behaviour was recorded for $120 \mathrm{mins}$ each in the morning (7.00-8.30 am) and evening (4.30-6.00 pm), twice per day with two days of observation per week for 7 weeks. Each kid was observed for 5 minutes and behavioural measurements such as suckling bout, duration of sucking, and the number of butts per sucking bout was recorded. Suckling behaviour of kids was observed with the use of digital camera and a stop watch in order to ensure that observation was done without been biased. A description of the three mutual exclusive behaviours monitored in this study is provided in Table 1.

Table 1: Ethogram of the three behaviour categories monitored

\begin{tabular}{ll}
\hline Behaviour & Description \\
\hline Suckling bout & The number of times the kid suckled the dam \\
Duration of suckling & $\begin{array}{l}\text { This is the time taken to suckle the dam } \\
\text { Number of butts per suckling }\end{array}$ \\
& $\begin{array}{l}\text { Number of time s the kids nudge the udder of the dam during } \\
\text { suckling }\end{array}$ \\
\hline
\end{tabular}

\section{Data collection}

Data was collected 4 times a week (morning and evening on each of the two days of observation per week) on three behavioural measurements namely suckling bout, duration of suckling, number of butts during suckling.

\section{Statistical analysis}

Data collected on suckling bout, duration of suckling and number of butts during suckling were analysed using separate Independent sample T-test having birth type (twin or singleton) and sex (male and female) as independent factors using SPSS statistical package version 16 . To establish the relationship between behavioural variables, Pearson's correlation was undertaken.

\section{Results}

Effect of birth type on suckling behaviour of WAD goat kids

Table 2 shows the effect of birth type on suckling behaviour of WAD goat kids. There was a significant effect of birth type on suckling bout, duration of suckling and number of butts during suckling $(\mathrm{p}<0.001)$. The number of suckling bout, duration of suckling and the number of butts during suckling was greater in twins than singleton. 


\section{Iyasere, James, Akinsanya, Williams and Daramola}

However, there was no significant effect of sex on suckling bout, duration of suckling and number of butts during suckling (Table $3)$. There were significant positive correlations between suckling bout and duration of suckling, between suckling bout and number of butts during suckling (Table 4).

Table 2: Effect of birth type on the suckling behaviour of West African dwarf goat kids

\begin{tabular}{lcc}
\hline Behaviour & \multicolumn{2}{c}{ Birth type } \\
\cline { 2 - 3 } & Singleton & Twin \\
\hline Suckling bouts & $0.41 \pm 0.07^{\mathrm{b}}$ & $0.90 \pm 0.05^{\mathrm{a}}$ \\
Duration of suckling (sec) & $48.6 \pm 8.40^{\mathrm{b}}$ & $102.0 \pm 9.60^{\mathrm{a}}$ \\
Number of butts during suckling & $1.32 \pm 0.24^{\mathrm{b}}$ & $2.70 \pm 0.15^{\mathrm{a}}$ \\
\hline \multicolumn{2}{c}{ ab means with different letters across a row differ significantly at $\mathbf{p}<\mathbf{0 . 0 0 1}$. Singleton $(\mathbf{n}=\mathbf{1 6})$ and twin $(\mathbf{n}=\mathbf{1 0})$. Values are Means } \\
$\quad$ S.E.
\end{tabular}

Table 3: Effect of sex on suckling behaviour of West African dwarf goat kids

\begin{tabular}{|c|c|c|}
\hline \multirow[t]{2}{*}{ Behaviour } & \multicolumn{2}{|c|}{ Birth type } \\
\hline & Male & Female \\
\hline Suckling bouts & $0.65 \pm 0.12$ & $0.55 \pm 0.80$ \\
\hline Duration of suckling (sec) & $73.8 \pm 0.13$ & $63.6 \pm 9.60$ \\
\hline Number of butts during suckling & $1.97 \pm 0.34$ & $1.74 \pm 0.30$ \\
\hline
\end{tabular}

Table 4: Correlation between suckling behaviour of West African dwarf goat kids

\begin{tabular}{|c|c|c|c|}
\hline & Suckling bout & Duration of suckling & No. of butts during suckling \\
\hline Suckling bout & 1.000 & & \\
\hline Duration of suckling & $0.961 * *$ & 1.000 & \\
\hline No. of butts during suckling & $0.988 * *$ & $0.970 * *$ & 1.000 \\
\hline
\end{tabular}

\section{Discussion}

Suckling is a pleasant event which is not associated with stress as evident from the lack of a significant change in heart rate or blood pressure of the kids during undisturbed suckling (von Walter, 2010). In this study, the duration of suckling was longer in twin than singleton. This result is in agreement with Martinez et al. (2009) who reported that the duration of suckling in the first hour after birth was longer in twin birth kids than in single birth kids (16 vs. 22s). From the first to the eight week of age, suckling duration was greater in twins than single (Alley et al., 1995). The longer duration of twin kids suckling their dams amount to increased stimulation of the udder which in turn could result in the increased milk production by the dam.
Researches have shown that dams with twin kids produced greater milk yield than their counterparts with single kids (Williams et al., 2015). Twice daily milking of WAD dams increased milk yield by $43 \%$ compared to once daily milking (Williams et al., 2012)

In the current study, the number of butts during suckling and suckling bouts was dependent on birth type and not sex of the kids. Butting of the udder by the kids could be describe as means of stimulating the udder to enhance milk ejection through the neuro-hormonal reflex that assist in the contraction of the myoepithelial cells around the alveoli because of the action of oxytocin released from the pituitary gland (Jorge and Merbis, 2003). Milking of cows prior to calf suckling was associated with 


\section{Suckling behaviour of West African dwarf goat kids}

longer duration of suckling in more frequent but shorter bouts and more butting and switching between teats (De-Passille et al., 2006). Stimulation of the udder (washing, drying, massaging and simulated butting with hand) before milking enhanced milk yield by $21.8 \%$ in WAD goats (Williams et al., 2016), however in sheep, stimulation of the udder (cleaning, drying and massing for 2 minutes) suppressed milk yield by $12 \%$ (Williams et al., 2014). This suggests that the influence of udder stimulation on milk yield is specie dependent.

The non-observance of a significant effect of sex on the duration of suckling observed in the current study agrees with the report of Ruiz-Miranda et al. (1998) who reported no sex difference in nursing (suckling) behaviour such as nursing time, nursing success, nursing attempts in one month old Alpine kids. Martinez et al. (2009) also found no difference in the attempt to suckle ( 82 vs. $85 \%$ ) or successful suckling (66 vs. $65 \%$ ) in males and females respectively. Single males suckled more frequently than single female kids however the duration of suckling was similar in both sexes (Alley et al., 1995).

The significant difference in number of times at which male come in contact with the udder was greater compared to their female counterpart (suckling bout). This result is in agreement with Alley et al. (1995) who reported that single birth males suckled more frequently than single birth females, but there was no sex difference in the duration of suckling bouts. Although female lambs displayed greater suckling duration per bouts but the total duration of suckling and suckling frequency were similar in male and female lambs (Teke and Akdag, 2011). The more the suckling bouts undertaken by the kids, the longer the duration of suckling which in turn amount into greater milk intake. In the first hour after birth, a negative correlation $(r=-0.893)$ was observed between latency to first suckle and duration of first suckling in MurcianoGranadina breed of goat (Martinez et al., 2009).

\section{Conclusion}

Suckling bout, duration of suckling and number of butts during suckling was greater in twins than singleton. These behavioural parameters were not affected by the sex of the kids. A significant positive correlation was observed between suckling bout and duration of suckling, between suckling bout and number of butts during suckling and between duration of suckling and number of butts during suckling.

\section{References}

Alley, J. C., Fordham, R. A and Minot, E. O. 1995. Mother-offspring interactions in feral goats a behavioural perspective of maternal investment.New Zealand Journal of Zoology, 22 (1) 17-23.

Awotwi, E. K., Agbodza, S., OppongAnane, K. and Fianu, F. K. 1999. Periparturient behaviour of West African Dwarf goat. Ghana Journal of Agricultural Science, 32: 95-100.

Baruwa, O. I. 2013. Empirical analysis of costs and returns to goat production under tropicalconditions. Journal of Livestock Science, 4: 44-50.

De-Passille, A. M. B. and Rushen, J. 2006. Calves' behaviour during nursing is affected by feeding motivation and milk availability. Applied Animal Behaviour Science, 101(3-4): 264275.

Ewbank, R. 1967. Nursing and suckling behaviour amongst Clun forest ewes and lambs. Animal Behaviour, 15 (23): 251-258. 


\section{Iyasere, James, Akinsanya, Williams and Daramola}

Iyasere, O. S., James, I. J., Lawal, K. O., Williams, T. J., Oke, O. E. and Iyasere, E. 2015. Physiological changes associated with a shortterm isolation of West African Dwarf does from kids. In Proceedings of the $20^{\text {th }}$ Annual Conference of Animal Science Association of Nigeria (ASANNIAS), Adebiyi, O. A., Ogunwole, O. A., Babayemi, O.J and Iyayi, E.A (Eds.), held on 6-10 ${ }^{\text {th }}$ September at the International Conference Centre, University of Ibadan, Ibadan, Oyo state, pp 9294. Published by ASAN, Nigeria.

James, I. J. and Osinowo, O. A. 2004. Relationship between udder measurement during pregnancy and partial daily milk yield in goats. Nigeria Journal of Animal Production, 31(1): 252-262.

Jorge, C. and Marbis, T. 2003. Cow calf relationship during milk yield and during milking and its effect on calf live weight gain. Livestock Research for Rural Development, 39(15): 1-10.

Keveme, E. E. 1988. Central mechanisms underlying the neural, and neuroendocrine determinants of maternal behaviour. Psychoneuroendocrinology, 13: 127-141.

Martinez, M., Otal, J., Ramírez, A., Hevia, M.L. and Quiles, A.2009. Variability in thebehaviour of kids born of primiparous goats during the first hour after parturition: Effect of the type of parturition, sex, duration of birth, and maternal behaviour. Journal of Animal Sciences, 87: 1772-1777.

Ogunniyi, L. T., Adepoju, A. A., Olagunju, F. I., Ojedokun, I. K and Ganiyu, M. O. 2014. Efficiency and livestock production in Oyo state of Nigeria. Journal of Animal Science Advances, 4(1): 690-698.

Price, E. O., Martinez, C. L and Coe, B. L. 1985. The effects of twinning on mother offspring behaviour in range beef cattle. Applied Animal Behaviour Science, 13: 309-320.

Ruiz-Miranda, C. R. and Chabert, J. L. 1998 . A puntes sobre elcomportamientoecologia De los cabrosferalesdeIslade Mona. In XVISimposiodelDepartamentodeR ecursosNaturalesde Puerto Rico (pp.30).San Juan, PR: DNR Press Y

Snyman, M. A. 2010. Influence of body weight, age and measurement system on reproduction of South African Angora goat does. South African Journal of Animal Science, 40: 41-52.

Teke, B. and Akdag, F. 2011. The effect of age, lactation number, sex and birth type on suckling and nursing behavior of Karayaka lambs. Economic, social and environmental sustainability in sheep and goat production systems p. 32 3-327.

von Walter, L. W. 2010. Physiological and behavioural responses to fear and discomfort in dogs and goats. Licentiate Thesis Swedish University of Agricultural Sciences, pp 46.

Williams, T. J., Osinowo, O. A., Smith O. F., James, I. J., Ikeobi, C. O. N., Onagbesan, O. M., Shittu, O. O. and Solola, F. T. 2012. Effects of milking frequency on milk yield, drymatter intake and efficiency of feed utilization in West African Dwarf goat. Archivos de Zootecnia, 
61: 457-465.

Williams, T. J., James, I. J., Adekoya, D. A., A bdulate f, M. R., Onabegun, L. O., Jinadu, S. O., Falade, Y. O., Adewunmi, O. O., Abioja, M. O. and Osinowo, O.A. 2014. Milk yield of West African Dwarf sheep as affected by udder stimulation, stage of lactation and parity. Nigerian Journal of Animal Production, 41(2): 71-80.

Williams, T. J., James, I. J., Adewunmi, O. O., Ozoje, M. O., Ajibola, A. T. and Ohayi, M. O. 2015. Milk yield and rectal temperature in West African Dwarf goats as affected by wattle and litter size. Nigerian Journal of Animal Production, 42(2):37-44.
Williams, T. J., Ohayi, M. O., Akinrele, L. N., Daramola, J. O., Oke, O.E. and Iyasere, O. S. 2016. Influence of udder stimulation, stage of lactation and parity on milk yield in West African Dwarf goats. Nigerian Journal of Animal Production, 43(1): 61-69.

Received: $11^{\text {th }}$ February, 2017

Accepted: 21 $1^{\text {st }}$ June, 2017 